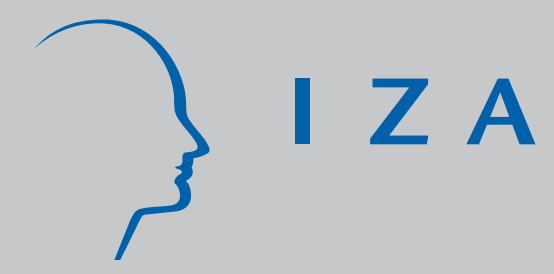

IZA DP No. 3541

The Role of Religion in Economic and

Demographic Behavior in the United States:

A Review of the Recent Literature

Evelyn L. Lehrer

J une 2008 


\title{
The Role of Religion in Economic and Demographic Behavior in the United States: A Review of the Recent Literature
}

\author{
Evelyn L. Lehrer \\ University of Illinois at Chicago \\ and IZA
}

Discussion Paper No. 3541

June 2008

IZA

P.O. Box 7240

53072 Bonn

Germany

Phone: +49-228-3894-0

Fax: +49-228-3894-180

E-mail: iza@iza.org

Any opinions expressed here are those of the author(s) and not those of IZA. Research published in this series may include views on policy, but the institute itself takes no institutional policy positions.

The Institute for the Study of Labor (IZA) in Bonn is a local and virtual international research center and a place of communication between science, politics and business. IZA is an independent nonprofit organization supported by Deutsche Post World Net. The center is associated with the University of Bonn and offers a stimulating research environment through its international network, workshops and conferences, data service, project support, research visits and doctoral program. IZA engages in (i) original and internationally competitive research in all fields of labor economics, (ii) development of policy concepts, and (iii) dissemination of research results and concepts to the interested public.

IZA Discussion Papers often represent preliminary work and are circulated to encourage discussion. Citation of such a paper should account for its provisional character. A revised version may be available directly from the author. 
IZA Discussion Paper No. 3541

June 2008

\section{ABSTRACT}

\section{The Role of Religion in Economic and Demographic Behavior in the United States: A Review of the Recent Literature*}

This paper presents a critical review and synthesis of recent research on the role of religion in economic and demographic behavior in the United States. Relationships reviewed include the effects of religion on investments in human capital, labor supply and wealth accumulation; union formation and dissolution; and fertility. The paper also comments on the growing literature on the implications of religious dissimilarity between the spouses; on two different, possibly countervailing ways in which religiosity may affect demographic and economic behavior; and on the importance of estimating models that allow for possible non-linearities in the effects of religiosity.

JEL Classification: J1, J2

Keywords: religion, marriage, divorce, education, fertility, female labor supply

Corresponding author:

Evelyn L. Lehrer

University of Illinois at Chicago

Economics Department (m/c 144)

601 South Morgan Street

Chicago, IL 60607-7121

USA

Email: elehrer@uic.edu

\footnotetext{
* I am indebted to Alicia Adsera, Carmel Chiswick, Chris Ellison, Jennifer Glass, and Lisa Pearce for valuable comments, and to Ramona Krauss and Zhenxiang Zhao for skillful research assistance.
} 


\section{The Role of Religion in Economic and Demographic Behavior in the United States: A Review of the Recent Literature}

The past few years have witnessed substantial progress in our understanding of how religious factors influence economic and demographic factors including education, female employment, fertility, and union formation and dissolution. In this paper I highlight results from recent studies on the role of religion in these and related economic and demographic behaviors, updating the critical literature review presented in an earlier article (Lehrer 2004a). Based on the theoretical framework suggested there, I also offer a reinterpretation of previous findings in the literature and identify promising avenues for

future research. The focus of this review is on the United States, but a few closely related studies that employ data from other countries are also included.

\section{A REINTERPRETATION OF PREVIOUS FINDINGS}

Analyses to date of how religion influences economic and demographic behavior have generally examined one relationship at a time, e.g., the religion-fertility linkage, the religion-female labor supply linkage, and so on. The broader perspective offered recently (Lehrer 2004a, 2000b), which emphasizes that in understanding any given relationship it is essential to consider the full picture, suggests a reinterpretation of previous findings in the literature and points towards a new direction for future analyses.

In his pioneering research and subsequent work, Goldscheider (1971, 1999, 2006) has made a distinction between fertility differences among religious groups that are attributable to (a) differences in socioeconomic and other demographic characteristics; 
and (b) specific teachings of the religion such as norms regarding contraception, and more importantly, broader value orientations and worldviews associated with the religion such as pronatalism or gender inequalities. Influenced by this theoretical framework, the approach that has generally been used in the literature to study how religion affects a particular demographic or economic outcome is to first estimate a zero order regression model, including only religion variables, and then add controls for other demographic and socio-economic factors. For example, Mosher et al. (1992) report results on overall differences in fertility between various religious groups, and the differences that remain after controlling for a series of demographic and socioeconomic variables including education. Yet religious affiliation has a substantial impact on investments in human capital (Chiswick 1988; Lehrer 1999b). Thus when a control for education is added to a fertility regression, the new, smaller coefficients on the religion variables leave out the indirect influence of religion on fertility via its impact on such investments.

This point applies to each of the other realms of economic and demographic behavior. For instance, in their analysis of the relationship between religious intermarriage and marital stability between waves I and II of the National Survey of Families and Households, Call and Heaton (1997) first report a zero order regression, and then another with controls for socioeconomic and demographic variables, including the birth of a child between the waves. The coefficient on the religious intermarriage variable becomes smaller in magnitude and loses all significance in this second regression. But religious intermarriage may lead to a reduced level of investments in spouse-specific human capital, children in particular, thus increasing the probability of marriage 
dissolution (Becker et al. 1977; Lehrer 1996). The small, insignificant coefficient on religious intermarriage in the second regression leaves out this indirect effect.

Future analyses should make a careful distinction between variables that are not influenced by religion, such as age, race, and ethnicity, properly held constant in the second regression, and those that are, such as investments in various forms of human capital, which should be excluded. This second regression would provide information on the total effects of religion. One might be tempted to go on to estimate a third regression including the latter variables so as to distinguish between direct and indirect influences, e.g., in the case of the religion-marital stability linkage discussed above, adding a variable for the birth of a child; however, marital stability and fertility are jointly determined. Thus this third step would generally be possible only when having access to a data set, or combination of data sets, rich enough to contain instruments that could be used to take these endogeneity issues into account.

\section{RELIGION AND DEMOGRAPHIC OUTCOMES}

An early study by Williams and Zimmer (1990) found that Catholics in Rhode Island had substantially higher fertility than non-Catholics, contrary to results that had begun to suggest an end to high Catholic fertility in the U.S. as a whole (Westoff and Jones 1979). The Williams-Zimmer study was among the first empirical analyses to emphasize the importance of the community context: Rhode Island is different from other states in that Catholics there constitute a majority. Similar analyses would probably reveal that the influence of religious factors on the demographic behavior of Jews in New York or Mormons in Utah differs substantially from that for their counterparts in places 
with smaller concentrations of coreligionists. McQuillan's (2004) work is an effort to advance our understanding of why the effects of religion on fertility vary across locations and over time. He presents evidence suggesting that religion matters when the religious institutions are able to articulate norms that are relevant to fertility and have the means to enforce compliance, and when individuals have a strong sense of attachment to their religious community. Berman et al. (2006) also emphasize the critical role of religious institutions, in a different dimension, namely, the extent to which they provide health, education, and other social services that affect the monetary costs of having children.

Fertility in the U.S. is considerably higher than that in most European countries, and indeed contrary to trends in other industrialized nations, the United States appears to be experiencing a baby boomlet; data for 2006 reveal the largest number of births since 1961 (Hamilton et al. 2007). Recent analyses of data for 13 developed countries shows that the ideal family size of individuals who have some religious affiliation is higher than that of their unaffiliated counterparts (Adsera 2006a), and for the case of Spain, a higher level of religiosity is associated with a faster tempo of births and also with higher fertility, by a small margin (Adsera 2006b). Related work for the United States shows that among more religious individuals both current and intended fertility are higher (Hayford and Morgan 2008). Although these results must be interpreted as purely descriptive, because religiosity is measured as of the survey date in the three studies, the results are suggestive of a positive influence of religiosity on fertility. An interesting question is the extent to which the difference in fertility between the U.S. and Europe is related to the much higher levels of religiosity and traditional family orientation that characterize the U.S. Analyses by Frejka and Westoff (2008) show that if the European 
countries had the same religiosity levels as the U.S., the fertility of women 18-44 would be higher than current levels by 13-14\% (depending on the measure of religiosity used). With regard to mortality, another major demographic outcome, previous studies have shown that some involvement in religious activities is generally associated with beneficial effects on health and survival rates (Waite and Lehrer 2003). A recent critical literature review concludes that there is strong evidence supporting a connection between public religious attendance and mortality risk, with weaker evidence for the case of private religious activities (Hummer et al. 2004). However, the question of whether or to what extent participation in religious activities causes better health outcomes remains controversial (e.g., see Bagiella et al. 2005, Hummer 2005). Related work on selfreported happiness, a proxy for overall well-being, shows that attendance to religious services can help buffer an individual's happiness against income shocks-- a finding that has implications for governmental provision of insurance (Dehejia et al. 2007). Although the linkages between religion and health/ well-being can have other, potentially far reaching economic implications, with few exceptions (Woodberry 2006) they have received virtually no attention in the literature to date. It is noteworthy also that participation in religious activities has been found to promote cooperative behavior, enhancing well-being for the entire community (Sosis and Ruffle 2003).

\section{RELIGION AND SOCIOECONOMIC OUTCOMES}

Earlier work has discussed possible pathways of causality linking religious affiliation and participation to schooling outcomes and educational attainment, key determinants of economic wellbeing (Chiswick 1988; Lehrer 1999b). Recent research 
suggests that religious factors are associated with the level of conflict between the parents (Curtis and Ellison 2002), domestic violence (Ellison et al. 1999), the degree of fathers' involvement with their children (King 2003, Wilcox 2004), the quality of mother-child relations (Pearce and Axinn 1998), and parenting styles and approaches to child discipline (Bartkowski and Wilcox 2000, Bartkowski et al. 2000). These studies suggest a number of other channels, which deserve further attention and quantification, through which religion may affect the home environment, the quality and quantity of informal investments in children's human capital, and educational outcomes.

Substantial progress has been made in recent years in understanding the effects of religion on other socioeconomic outcomes including labor supply, wages, and wealth. With regard to labor supply, although there is heterogeneity within conservative religious groups regarding views on appropriate roles for women and men (Gay et al. 1996), conservative Protestant groups generally provide psychological rewards and institutionalized moral support to women who stay home with their young children, and there is growing evidence of a distinctive pattern of female labor supply behavior among such groups (Lehrer 1995, 1999a; Sherkat 2000; Glass and Jacobs 2005; Glass and Nath 2006). Substantial, related differences in wages have also been found; thus future economic analyses of the male-female wage gap-- its magnitude, causes, and changes over time-- should consider the role of religious factors, including the growth of conservative Protestant denominations in the U.S. (Glass and Nath 2006, Lehrer 2008a). The possible role of religion on the labor supply behavior of men has received less attention in the literature, as it is unusual for prime-aged men to depart from a pattern of full- time work. Research in progress is examining this issue (Civettini and Glass 2008). 
Religion has also been found to have a large impact on wealth, both directly, by defining worthwhile objectives (oriented to this world and/or the afterlife) and providing tools for the development of savings and investment strategies, and indirectly, through its effects on education, fertility, and labor supply behavior (Keister 2003, 2005, 2008a, 2008b). Wealth differentials by religion mirror the patterns that have been found for education and wages: conservative Protestants have the lowest levels of wealth; Jews are at the other end of the spectrum, and mainline Protestants and Catholics are at the center of the distribution.

\section{THE IMPLICATIONS OF RELIGIOUS DISSIMILARITY}

The most recent study on this topic shows that the prevalence of religious intermarriage in the U.S. has been rising for all groups except conservative Protestants (Sherkat 2004), confirming the patterns found in earlier work (Lehrer 1998). Differences in religious affiliation between husband and wife have repercussions for marital stability, depending in part on the ecumenical/ exclusivist nature of the religions (Lehrer and Chiswick 1993) and such differences may also affect fertility and female labor supply (Becker et al. 1977; Lehrer 1995, 1996). Recent studies have found further confirmation for the importance of religious heterogamy for marital stability (Kalmijn et al. 2005), fertility (Adsera 2006b, 2006c), and female labor supply (Glass and Nath 2006).

New findings on the age at marriage--divorce relationship suggest that the implications of religious intermarriage for marital stability (and hence also for fertility and female labor supply) may vary by age at marriage (Lehrer 2008b). In this recent work 
I found that women who are unconventional in marrying for the first time in their late twenties or thirties tend to be unconventional also in being more likely to wed partners who have had a previous marriage and who differ from them substantially in age, education, race/ ethnicity, and also religion; yet their marriages are very stable. I interpreted these results as reflecting the importance of Valerie Oppenheimer's (1988) "maturity effect"-- the greater emotional maturity that comes with older ages, the better self-knowledge, and the greater ability to assess the likely trajectory of potential partners. A greater appreciation of the benefits from marriage--especially having a partner with whom to have and raise a child-- probably plays an important role also. Thus it seems likely that replication of earlier analyses in the literature separately by age at entry into first marriage would reveal that the destabilizing effect associated with religious intermarriage is small or non-existent in the sub-sample of late entrants into first marriage. The potential fruitfulness of this line of investigation is suggested by the current trend towards increasingly delayed entry into first formal union (Lehrer 2008b). Differences in religion between the parents lead to subsequent religious dissimilarity between at least one parent and the children, generating a potential source of conflict within the family; such intergenerational dissimilarity may arise also in households where the parents share the same religious affiliation, if a child chooses to follow a different path. Sherkat and Darnell (1999) find that conservative Protestant parents are less willing to make investments in higher education for children who do not follow their faith. Recent work has also found an association between parent-child religious dissimilarity and child's law abiding behavior: when the mother is very religious 
and the child is not, or viceversa, there is an elevated risk of adolescent delinquency (Pearce and Hayne 2004).

\section{TWO WAYS IN WHICH RELIGIOSITY MATTERS FOR DEMOGRAPHIC AND ECONOMIC BEHAVIOR}

Commitment to religion--in its various manifestations, including the strength of religious beliefs and the extent of participation in private and public religious activities-can affect demographic and economic behavior via two major pathways. First, a higher level of religiosity may be expected to accentuate the effects of religious affiliation, e.g., the tendency for conservative Protestant women to display low levels of employment when young children are present in the household should be most pronounced among highly observant conservative Protestant couples. Second, the generally beneficial effects of religiosity on health and well-being can have important implications for economic and demographic outcomes, e.g., children raised with some religious involvement in their lives tend to have better performance in school and to achieve a higher level of educational attainment. Analyses in the literature to date typically consider only one of these two pathways of causality. More recent work emphasizes the importance of taking both into account: the two pathways may exert countervailing influences, and in addition, the effects of religiosity may vary by religious affiliation (Lehrer 2006, 2008a).

The growing body of evidence showing that some involvement in religious activity is associated with better schooling outcomes has implications for the literature on the benefits of attendance to Catholic schools (e.g., Neal 1997; Altonji et al. 2005). Cohen-Zada and Sander (2008) note that most of these studies have failed to consider the 
comparatively high level of religiosity among children enrolled in Catholic schools, thus overstating the advantage associated with attendance to such schools with regard to test scores, high-school graduation rates, and other educational outcomes.

Analyses that have found beneficial influences of religiosity on various health and economic outcomes have generally specified religiosity as either a continuous religious participation variable, or a dichotomous variable for high versus low attendance to religious services. Chiswick and Huang (2007) use a set of dummy variables for various levels of participation, thus allowing for the possibility of non-linearities. Based on data from the 2000/2001 National Jewish Population Survey, they find that individuals who attend religious services weekly have significantly higher earnings than those who attend less frequently, supporting the hypothesis that some religious involvement has a beneficial effect on labor market outcomes; however, those who attend religious services more than weekly have lower earnings than those who attend weekly. The authors suggest that beyond a point, time and effort allocated to religious activities begins to crowd out time and effort that could be oriented to labor market activities. They also point out that discrimination in the labor market and lifestyle restrictions associated with the Orthodox denomination may play a role.

Unusually high rates of participation are often associated with extreme positions that may not be conducive to wellbeing, and non-linearities may emerge for this reason as well. A recent study of intimate partner violence in Chile finds that college women raised with some religious involvement in their lives are less likely to experience intimate partner violence, a result traced to their generally healthier, less risky lifestyles. However, there is no protective effect for women raised with high levels of religious participation. 
Such women probably include many raised with extreme views and role models, where the sacredness of family unity is seen as foremost even in the face of spousal abuse, and where submissiveness is viewed as a key female quality (Lehrer et al. 2007). Future research should use statistical specifications that allow for possible non-linearities. The key question is whether beyond a certain point, further increases in the level of religiosity have an insignificant or even adverse influence.

Related to this, although the U.S. literature on religion and health overwhelmingly points towards benefits associated with religion, there are exceptions, particularly in the area of sexuality. The abstinence-only programs advocated by conservative religious groups have been found to be ineffective in reducing the risk of pregnancy or sexually transmitted diseases among teens (Kirby 2001, Trenholm et al. 2007), and while most studies have found that high levels of religiosity are associated with delayed sexual debut, results to date on the connection between religiosity and sexual risk behaviors among sexually active adolescents have been mixed (Whitehead et al. 2001). A better, more nuanced understanding of the effects of religion on health and economic outcomes requires further attention to these and other important exceptions.

\section{SMALLER RELIGIOUS AND ETHNIC/ RACIAL GROUPS}

Most of the studies in the U.S. literature on the role of religion in economic and demographic behavior have been based on samples of non-Hispanic whites, with a focus on the large religious groups-- Catholics, mainline Protestants, and conservative Protestants. Recent research has begun to analyze samples of racial/ ethnic and religious minorities (Warner 2002; Read 2004; Glass and Jacobs 2005; Wilcox and Wolfinger 
2006; C. Chiswick 2007, 2008; B. Chiswick 2008). Further research on these smaller groups would be desirable. The "no-religion" group, which grew in size from $8 \%$ of the population in 1990 to over 14\% in 2001, also deserves additional attention (Kosmin and Keysar 2006).

\section{MEASUREMENT AND STATISTICAL ISSUES}

Much of what we know about the connection between religion and economic/ demographic behavior is based on analyses that use only two indicators of religion: broad categories of religious affiliation and frequency of attendance to religious services, usually measured during childhood. Recent research suggests the fruitfulness of considering more detailed categories of religious affiliation (Barrett et al. 2007); a richer array of dimensions of religion, including beliefs (e.g., in the existence of God, miracles, the inerrancy of the Bible), the salience of religion, and private religiosity (Idler et al. 2003; Kosmin and Keysar 2006; Glass and Nath 2006); and measures of parental religious affiliation and participation (Pearce and Thornton 2007; Branas-Garza and Neuman 2007).

One of the main reservations expressed with regard to results that show beneficial effects of religious participation in various areas is that such effects may be overstated, because the estimates include the influence of unmeasured positive characteristics that are correlated with religiosity (e.g., Freeman 1986; Regnerus and Smith 2005). For example, if parents who encourage their children to attend religious services also tend to encourage them to do their homework and engage in other constructive behaviors, part of the observed positive association between religious participation and educational 
outcomes would reflect the influence of these other behaviors. However, to the extent that religious participation is especially beneficial for those who are more vulnerable (for reasons that might include poor health, unfavorable family circumstances, and adverse economic conditions), the estimated coefficients may actually understate the true effect of religiosity (Lehrer 2004c). Thus although the most serious concern expressed in this literature has been that the estimates overstate the effects, it may well be the case that the opposite is true.

Recent work by Barro and McCleary (2003) and Gruber (2005) uses instrumental variables methods to estimate the causal effects of participation in religious activities; additional efforts in this direction would be desirable. This approach offers promise in addressing endogeneity issues in connection with the effects of religious intermarriage (as discussed in Lehrer and Chiswick (1993), the same unobserved factors that lead an individual to enter an interfaith marriage may later influence the stability of the union); with the controversial religiosity- health relationship; and with the linkages between religiosity and each of the economic and demographic behaviors discussed in this article. While the theoretical arguments for these linkages are compelling and the evidence accumulated to date suggests that the magnitudes of the effects are likely not trivial, we need additional research that addresses concerns of reverse causality and confounding factors. 


\section{CONCLUDING REMARKS}

The studies reviewed here describe the effects of religion on various economic and demographic behaviors, including education, female employment, wealth, fertility, and union formation and dissolution. Causality also flows in the opposite direction, and there is a growing literature that seeks to understand how economic and demographic variables influence the extent and form of involvement in religious activities, the process of switching from one religious affiliation to another, and other dimensions of religious behavior (for some recent contributions, see Branas-Garza and Neuman 2004; Barro and Hwang 2007; Zhai et al. 2007; C. Chiswick 2008; Waite and Lewin 2008). A major challenge that lies ahead is the need to do more to understand and model the reciprocal influences linking religion and economic/demographic behavior. The impressive recent advances in the field reviewed in this article bode well for continued progress. 


\section{REFERENCES}

Adsera, A. (2006a) "Religion and Changes in Family-Size Norms in Developed Countries." Review of Religious Research 47(3):271-286.

(2006b) "Marital Fertility and Religion in Spain, 1985 and 1999." Population Studies 60(2): 205-221.

(2006c) "An Economic Analysis of the Gap between Desired and Actual Fertility: The Case of Spain." Review of Economics of the Household 4: 75-95.

Altonji, J.G., Elder, T.E., and Taber, C.R. (2005) "Selection on Observed and Unobserved Variables: Assessing the Effectiveness of Catholic Schools." Journal of Political Economy 113: 151-184.

Bagiella, E., Hong, V., Sloan, R.P. (2005) "Religious Attendance as a Predictor of Survival in the EPESE Cohorts." International Journal of Epidemiology 34:443451.

Barrett, J.B., Ellison, C.G., and Grammich, C. (2007) "Religious Influences on American Opinion about Family Planning." Unpublished manuscript.

Barro, R.J. and McCleary, R. (2003) "Religion and Economic Growth." American Sociological Review 68 (October): 760-781.

Barro, R.J. and Hwang, J. (2007) "Religious Conversion in 40 Countries." Unpublished manuscript.

Bartkowski, J.P. and Wilcox, W.B. (2000) "Conservative Protestant Child Discipline: The Case of Parental Yelling." Social Forces 79: 865-891.

Bartowski, J. P., Wilcox, B. and Ellison, C. G. (2000) "Charting the Paradoxes of Evangelical Family Life: Gender and Parenting in Conservative Protestant Households." Family Ministry 14(4):9-21.

Becker, G. S., Landes, E. M., Michael, R. T. (1977) “An Economic Analysis of Marital Instability.” Journal of Political Economy 85(6):1141-1187.

Berman, E., Iannaccone, L.R. and Ragusa, G. (2006) "From Empty Pews to Empty Cradles: Fertility Decline Among European Catholics." Presented at the annual meetings of the Economic Association of America, Chicago.

Branas-Garza, P. and Neuman, S. (2004) "Analyzing Religiosity within an Economic Framework: The Case of Spanish-Catholics." Review of Economics of the Household 2:52-44. 
(2007) "Parental Religiosity and Daughters' Fertility: The Case of Catholics in Southern Europe, Review of Economics of the Household 5(3):305-327.

Call, V.R.A. and Heaton, T.B. (1997) "Religious Influence on Marital Stability." Journal for the Scientific Study of Religion 36(3): 382-392.

(1988) "Differences in Education and Earnings Across Racial and Ethnic Groups: Tastes, Discrimination, and Investments in Child Quality.” Quarterly Journal of Economics 103(3):571-597.

Chiswick, B. (2008) "The Rise and Fall of the American Jewish PhD." IZA Discussion Paper.

Chiswick, B. and Huang, J. (2007). "The Earnings of American Jewish Men: Human Capital, Denomination, and Religiosity." Presented at the annual meetings of the Illinois Economic Association, Chicago.

Chiswick, C. (2007) "Judaism in Israel and the United States: An Economic Perspective." Pp. 131-154 in C. Chiswick, T. Lecker, and N. Kahana (eds.) Jewish Society and Culture: An Economic Perspective. Ramat Gan, Israel: Bar-Ilan University Press.

- - - - (2008) The Economics of American Judaism. London and New York: Routledge.

Civettini, N.H. and Glass, J. (2008) "The Impact of Religious Conservatism on Men's Work and Family Involvement." Unpublished manuscript.

Cohen-Zada, D. and Sander, W. (2008) "Religion, Religiosity and Private School Choice: Implications for Estimating the Effectiveness of Private Schools." Forthcoming in Journal of Urban Economics.

Curtis, K.T. and Ellison, C.G. (2002) "Religious Heterogamy and Marital Conflict: Findings from the National Survey of Families and Households." Journal of Family Issues 23(4):551-576.

Dehejia, R., DeLeire, T., Luttmer, E.F.P. (2007) "Insuring Consumption and Happiness through Religious Organizations." Journal of Public Economics 91:259-279.

Ellison, C. G., Bartkowski, J. P. and Anderson, K. L. (1999) “Are There Religious Variations in Domestic Violence?” Journal of Family Issues 20(1):87-113.

Freeman, Richard B. 1986. "Who Escapes? The Relationship of Churchgoing and Other Background Factors to the Socioeconomic Performance of Black Male Youths from Inner-City Tracts,” Pp. 353-376 in R.B. Freeman and H. J. Holzer (eds.), The Black Youth Employment Crisis, Chicago: The University of Chicago Press. 
Frejka, T. and Westoff, C.F. (2008) "Religion, Religiousness and Fertility in the US and in Europe." Forthcoming in European Journal of Population.

Gay, D.A., Ellison, C.G., and Powers, D.A. (1996) "In Search of Denominational Subcultures: Religious Affiliation and Pro-Family Issues Revisited." Review of Religious Research 38:3-17.

Glass, J and Jacobs, J. (2005) "Childhood Religious Conservatism and Adult Attainment among Black and White Women." Social Forces 84(1): 555-579.

Glass, J. and Nath, L.E. (2006) "Religious Conservatism and Women's Market Behavior Following Marriage and Childbirth." Journal of Marriage and the Family 68(August): 611-629.

Goldscheider, C. (1971) Population, Modernization, and Social Structure. Boston: Little, Brown.

(1999) "Religious Values, Dependencies, and Fertility: Evidence and Implications from Israel." Pp. 310-330 in R. Leete (ed.) Dynamics of Values in Fertility Change, Oxford: Oxford University Press.

(2006) "Religion, Family, and Fertility: What do We Know Historically and Comparatively?" Pp. 41-58 in R. Derosas and F. van Poppel (eds.), Religion and the Decline of Fertility in the Western World, The Netherlands: Springer.

Gruber, J. (2005) "Religious Market Structure, Religious Participation, and Outcomes: Is Religion Good for You?” Advances in Economic Analysis and Policy 5(1): article 5. http://www.bepress.com/bejeap/advances/vol5/iss1/art5

Hamilton, B.E., Martin, J.A., and Ventura, S.J. (2007) "Births: Preliminary Data for 2006." National Vital Statistics Reports 56(7). Available at http://www.cdc.gov/nchs/data/nvsr/nvsr56/nvsr56_07.pdf. Accessed February 1, 2008.

Hayford, S.R. and Morgan, S.P. (2008) "Religiosity and Fertility in the United States: The Role of Fertility Intentions." Forthcoming in Social Forces.

Hummer, R.A. (2005) "Commentary: Understanding Religious Involvement and Mortality Risk in the United States: Comment on Bagiella, Hong, and Sloan." International Journal of Epidemiology 34:452-453.

Hummer, R.A., Ellison, C.G., Rogers, R.G., Moulton, B.E., and Romero, R.R. (2004) "Religious Involvement and Adult Mortality in the United States: Review and Perspective." Southern Medical Journal 27(12):1223-1230. 
Kalmijn M., de Graaf P.M., Janssen J.P. (2005) "Intermarriage and the Risk of Divorce in the Netherlands: The Effects of Differences in Religion and in Nationality, 1974-94." Population Studies 59(1): 71-85.

Idler, E.L., Musick, M.A., Ellison, C.G., George, L.K., Krause, N, Ory, M.G., Pargament, K.I., Powell, L.H., Underwood, L.G., and Williams, D.R. "Measuring Multiple Dimensions of Religion and Spirituality for Health Research: Conceptual Background and Findings from the 1998 General Social Survey." Research on Aging 25:327-365.

Keister, L.A. (2003) "Religion and Wealth: The Role of Religious Affiliation and Participation in Early Adult Asset Accumulation." Social Forces 82: 173-205. (2005) Getting Rich: America's New Rich and How They Got that Way. Cambridge: Cambridge University Press.

(2008a) "Childhood Religious Denomination and Early Adult Asset Accumulation." Forthcoming in C. Ellison and R. Hummer (eds.) Religion, Family Life, and Health in the United States, Rutgers University Press.

(2008b) "Conservative Protestants and Wealth: How Religion Perpetuates Asset Poverty." Forthcoming in American Journal of Sociology.

King, V. (2003) "The Influence of Religion on Fathers' Relationships with Their Children." Journal of Marriage and the Family 65:382-395.

Kirby, D. (2001) Emerging Answers: Research Findings on Programs to Reduce Teen Pregnancy. Washington, DC: National Campaign to Prevent Teen Pregnancy.

Kosmin B.A. and Keysar, A. (2006) Religion in a Free Market. Ithaca, New York: Paramount Market Publishing, Inc.

Lehrer, E.L. (1995) "The Effects of Religion on the Labor Supply of Married Women.” Social Science Research 24: 281-301. (1996) “Religion as a Determinant of Fertility.” Journal of Population Economics 9: 173-196.

(1998) "Religious Intermarriage in the United States: Determinants and Trends." Social Science Research 27: 245-263.

(1999a) “Married Women’s Labor Supply Behavior in the 1990s: Differences by Life-Cycle Stage.” Social Science Quarterly 80(3): 574-590. 
(1999b) "Religion as a Determinant of Educational Attainment: An Economic Perspective.” Social Science Research 28: 358-379.

(2004a) "Religion as a Determinant of Economic and Demographic Behavior in the United States.” Population and Development Review 30(4): 707-726.

(2004b) “The Role of Religion in Union Formation: An Economic Perspective.” Population Research and Policy Review 23(2): 255-275.

(2004c) "Religiosity as a Determinant of Educational Attainment: The Case of Conservative Protestant Women in the United States.” 2004. Review of Economics of the Household 2(2): 203-219.

(2006) "Religion and High School Graduation: A Comparative Analysis of Patterns for White and Black Young Women.” Review of Economics of the Household 4(3): 277-293.

(2008a) "Religious Affiliation and Participation as Determinants of Women’s Educational Attainment and Wages.” Forthcoming in C. Ellison and R. Hummer (eds.) Religion, Family Life, and Health in the United States. Rutgers University Press.

(2008b) “Age at Marriage and Marital Instability: The Becker-Landes-Michael Hypothesis Revisited.” Forthcoming in Journal of Population Economics.

Lehrer, E.L. and Chiswick, C. (1993) "Religion as a Determinant of Marital Stability.” Demography 30(3): 385-404.

Lehrer, E.L., Lehrer, V.L., and Krauss, R. (2007) "Religion and Intimate Partner Violence in Chile: Macro- and Micro- Level Influences." Presented at the annual meetings of the Illinois Economic Association, Chicago.

McQuillan, K. (2004) "When does Religion Influence Fertility?" Population and Development Review 30(1): 25-56.

Mosher, W.D., Williams, L.B., and Johnson, D.P. (1992) "Religion and Fertility in the United States: New Patterns." Demography 29(2): 199-214.

Neal, D. (1997) "The Effects of Catholic Secondary Schooling on Educational Achievement." Journal of Labor Economics 15(1):98-123.

Oppenheimer V.K. (1988) "A Theory of Marriage Timing." American Journal of Sociology 94: 563-91. 
Pearce, L.D. and Axinn, W.G. (1998). "The Impact of Family Religious Life on the Quality of Mother-Child Relations." American Sociological Review 63(6): 810-828.

Pearce, L.D. and Haynie, D.L. (2004) "Intergenerational Religious Dynamics and Adolescent Delinquency." Social Forces 82(4):1553-1572.

Pearce, L.D. and Thornton, A. (2007). "Religious Identity and Family Ideologies in the Transition to Adulthood." Journal of Marriage and the Family 69:1227-1243.

Read, J.G. (2004) Culture, Class and Work Among Arab-American Women. New York: LFB Scholarly Publishing LLC.

Regnerus, M. and Smith, C. (2005) "Selection Effects in Studies of Religious Influence." Review of Religious Research 47(1): 23-50.

Sherkat, D. E. (2000) "That They be Keepers of the Home: The Effect of Conservative Religion on Early and Late Transition into Housewifery.” Review of Religious Research 41(3): 344-358. (2004) "Religious Intermarriage in the United States: Trends, Patterns, and Predictors.” Social Science Research 33: 606-625.

Sherkat, D. E., and Darnell, A. (1999) “The Effects of Parents’ Fundamentalism on Children's Educational Attainment: Examining Differences by Gender and Children's Fundamentalism. ”Journal of the Scientific Study of Religion 38(1):23-35.

Sosis, R. and Ruffle, B. (2003) "Religious Ritual and Cooperation: Testing for a Relationship on Israeli Religious and Secular Kibbutzim." Current Anthropology 44(5):713-722.

Trenholm, C., Devaney, B., Forston, K., Quay, L., Wheeler, J., and Clark, M. (2007) Impacts of Four Title V, Section 510 Abstinence Education Programs. Mathematica Policy Research, Inc. Available at: http://www.mathematica-mpr.com/publications/pdfs/impactabstinence.pdf Accessed March 18, 2008.

Waite, L. and Lehrer, E. (2003) "The Benefits from Marriage and Religion in the United States.” Population and Development Review 29(2): 255-275.

Waite, L.J. and Lewin, A.C. (2008) "Religious Intermarriage and Conversion in the United States: Patterns and Changes Over Time." Forthcoming in C. Ellison and 
R. Hummer (eds.) Religion, Family Life, and Health in the United States, Rutgers University Press.

Warner, R. S. 2002. "The Black Church as the Village it Takes to Raise a Child." Youth and Religion Project, Module 1. Available at http://www.uic.edu/depts/soci/yrp/index1.html. Accessed February 15, 2008.

Westoff, C.F. and Jones, E.F. (1979) "The End of 'Catholic' Fertility." Demography 16: 209-218.

Whitehead, B.D., Wilcox, B.L., and Rostosky, S.S. (2001) Keeping the Faith: The Role of Religion and Faith Communities in Preventing Teen Pregnancy. Washington, D.C.: The National Campaign to Prevent Teen Pregnancy.

Wilcox, W.B. (2004) Soft Patriarchs, New Men: How Christianity Shapes Fathers and Husbands. Chicago: The University of Chicago Press.

Wilcox, W.B. and Wolfinger, N.H. (2006) "Then Comes Marriage? Religion, Race, and Marriage in Urban America." Social Science Research 36:569-589.

Williams, L. and Zimmer, B.G. (1990) "The Changing Influence of Religion on U.S. Fertility: Evidence from Rhode Island." Demography 27(3): 475-481.

Woodberry, R.D. (2006) "The Economic Consequences of Pentecostal Belief." Society 44(1): 29-35.

Zhai, J.E., Ellison, C.G., Glenn, N.D. and Marquardt, E. (2007) "Parental Divorce and Religious Involvement among Young Adults." Sociology of Religion 68(2): 125144. 